\title{
Mediator-free microfluidics biosensor based on titania- zirconia nanocomposite for urea detection
}

\author{
Saurabh Srivastava, ${ }^{\text {ab }}$ Md. Azahar Ali, ${ }^{a}$ Pratima R. Solanki, ${ }^{a}$ Pandurang M. Chavhan, ${ }^{a}$ \\ Manoj K. Pandey, ${ }^{a}$ Ashok Mulchandani, ${ }^{c}$ Anchal Srivastava ${ }^{b}$ and Bansi D. Malhotra*d \\ Urease (Urs) and glutamate dehydrogenase (GLDH) co-immobilized onto titania-zirconia $\left(\mathrm{TiO}_{2}-\mathrm{ZrO}_{2}\right)$ \\ nanocomposite and integrated with microfluidics mediator-free sensor have been utilized for urea \\ detection. The PDMS microchannels have been sealed with a glass substrate comprising of reference (Ag/ \\ $\mathrm{AgCl}$ ), counter (ITO) and working (Urs-GLDH/TiO $\left.-\mathrm{ZrO}_{2} / \mathrm{ITO}\right)$ electrodes. This mediator-free microfluidics \\ urea sensor shows linearity as $5-100 \mathrm{mg} / \mathrm{dL}$ with improved sensitivity as $2.74 \mu \mathrm{A}$ [Log mM] $]^{-1} \mathrm{~cm}^{-2}$ and \\ detection limit of $0.07 \mathrm{mg} / \mathrm{dl}(0.44 \mathrm{mM})$ using $3 \sigma_{\mathrm{b}} / \mathrm{m}$ criteria. The Reynolds number has been found to be

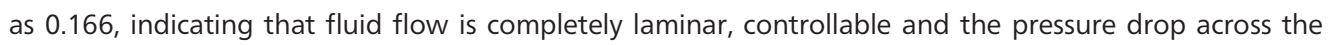 \\ microchannels is found to be as $3.5 \times 10^{3} \mathrm{~Pa}$.
}

Received 16th July 2012,

Accepted 24th October 2012

DOI: $10.1039 / \mathrm{c} 2 \mathrm{ra21461j}$

www.rsc.org/advances isoelectric point, non-toxicity, chemical stability, biocompatibility and high electron transfer ability. ${ }^{10-12}$

The estimation of urea is important for clinical analysis, since increased urea level in blood and urine causes various kidney diseases. ${ }^{13-15}$ We report results of the studies relating to development of mediator-less microfluidics device based on $\mathrm{TiO}_{2}-\mathrm{ZrO}_{2}$ nanocomposite for urea detection. It is found that presence of this binary oxide facilitates direct electron transfer between active sites of the enzymes to the electrode. It has been reported that addition of $\mathrm{ZrO}_{2}$ to $\mathrm{TiO}_{2}$ can prevent phase transformation from anatase to rutile, lead to enhanced catalytic, photocatalytic and electrochemical properties due to modification in electronic band structure and interfacial state. ${ }^{16-18}$ To the best of our knowledge, we are reporting for the first time a $\mathrm{TiO}_{2}-\mathrm{ZrO}_{2}$ nanocomposite incorporated mediatorfree microfluidics sensor for urea detection.

\section{Experimental section}

\subsection{Chemicals}

All chemicals have been procured from Sigma Aldrich. Sylgard 184 is procured from Dow Corning (Midland, MI, USA). SU-8100 negative photoresist and SU-8 developer have been acquired from Microchem (Newton, MA, USA).

\footnotetext{
${ }^{a}$ Department of Science and Technology Centre on Biomolecular Electronics, Biomedical Instrumentation Section, National Physical Laboratory, New Delhi, 110012, India

${ }^{b}$ Department of Physics, Banaras Hindu University, Varanasi, 221005, UP, India ${ }^{c}$ Department of Chemical and Environmental Engineering, University of California, Riverside, CA, 92521, USA

${ }^{d}$ Department of Biotechnology, Delhi Technological University, Main Bawana Road, Delhi, 110042, India. E-mail: bansi.malhotra@gmail.com; Tel: 91-11-27871043 (Ext-1609)
}

\subsection{Synthesis of $\mathrm{TiO}_{2}-\mathrm{ZrO}_{2}$ nanocomposite}

Zirconium (IV) n-propoxide and titanium(Iv) butoxide (1:1 molar ratio) are dissolved in 2-methoxy ethanol to prepare $5(\mathrm{wt} \%)$ precursor sol solution and hydrolyzed by drop wise addition of $500 \mu \mathrm{l}$ of $\mathrm{H}_{2} \mathrm{O}$ and nitric acid $(25 \mu \mathrm{l}$ of $70 \%)$ under 


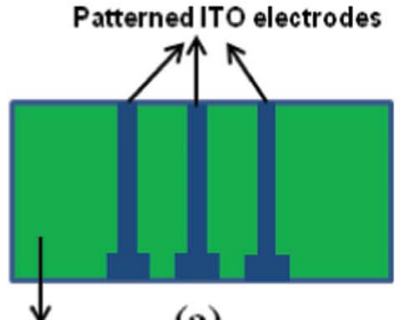

(a) Glass substrate

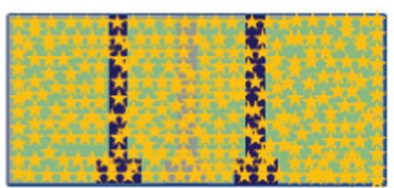

(d)

Removing the cello film from the rest of the region

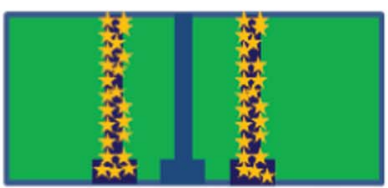

(e)

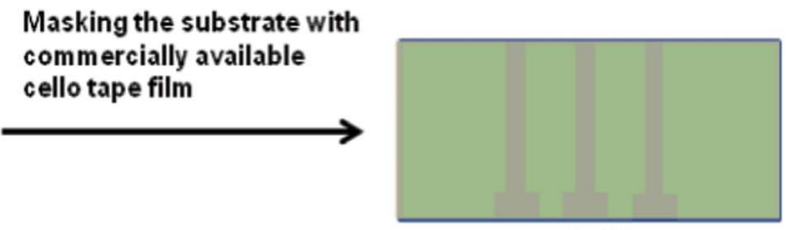

(b)

\section{Removing the film \\ from working \\ electrodes with a \\ sharp razor blade}

Dip coating with sol-gel solution followed by drying at $90^{\circ} \mathrm{C}$ for $1 \mathrm{~h}$

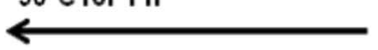

High tem perature annealing (450 $\mathrm{C}$ for $2 \mathrm{hrs}$ )

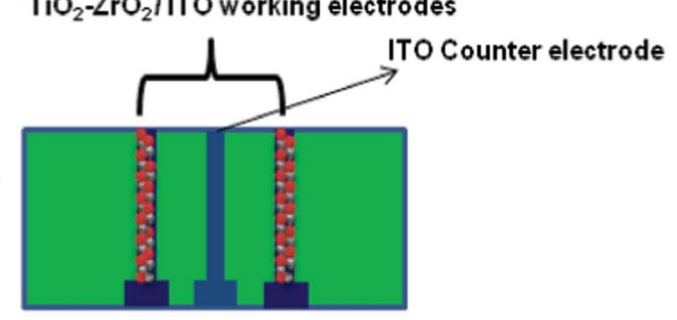

(f)

Scheme 1 The process of modifying only the working ITO electrode (WE1 and WE 2) with $\mathrm{TiO}_{2}-\mathrm{ZrO}_{2}$ nanocomposite using the dip coating method is shown.

continuous stirring followed by keeping for about $2 \mathrm{~h}$ at $25{ }^{\circ} \mathrm{C}$ for ageing.

\subsection{Fabrication of microfluidics electrodes and microchannels}

Two patterned microelectrodes comprising of dimensions $\left(0.2 \times 2.5 \mathrm{~cm}^{2}\right)$ are fabricated onto indium tin oxide (ITO) coated glass slide $\left(2.5 \times 3.5 \mathrm{~cm}^{2}\right)$ by wet chemical etching process. The working electrodes (WE 1 and WE 2) are used to deposit $\mathrm{TiO}_{2}-\mathrm{ZrO}_{2}$ nanocomposite film by dip coating method (Scheme 1). For this process, first we take the glass substrate containing three patterned ITO electrodes (step a, Scheme 1) that is masked with commercially available cello tape film (step b). We then remove the cello tape from the two patterned ITO electrodes using a sharp razor blade (step c), leaving central ITO microelectrode and the substrate remains covered. This substrate is dip coated with transparent sol-gel solution followed by drying at $90{ }^{\circ} \mathrm{C}$ for $1 \mathrm{~h}$ (step d). The remaining cello tape film is then removed from the rest of the substrate. The dried sol-gel film onto patterned ITO electrodes is finally annealed at $450{ }^{\circ} \mathrm{C}$ for $2 \mathrm{~h}$ to obtain $\mathrm{TiO}_{2}-\mathrm{ZrO}_{2}$ nanocomposite (step e). In this process, the central bare patterned ITO electrode remains unmodified with sol-gel coating that is used as the counter electrode. The proposed reactions involved in the synthesis of $\mathrm{TiO}_{2}-\mathrm{ZrO}_{2}$ nanocomposite are as follows:

$$
\begin{aligned}
& \mathrm{Zr}\left(\mathrm{OC}_{3} \mathrm{H}_{7}\right)_{4}+\mathrm{HO}-\mathrm{CH}_{2}-\mathrm{CH}_{2}-\mathrm{O}-\mathrm{CH}_{3}+\mathrm{H}_{2} \mathrm{O} \stackrel{\mathrm{HNO}_{3}, \text { Hydrolysis }}{\longrightarrow} \\
& \mathrm{Zr}\left(\mathrm{OC}_{3} \mathrm{H}_{7}\right)_{2}(\mathrm{OH})_{2}+2 \mathrm{C}_{3} \mathrm{H}_{7} \mathrm{OH} \stackrel{\text { Polycondensation }}{\longrightarrow} \\
& \quad \mathrm{Sol} \\
& {\left[\mathrm{Zr}(\mathrm{OH})_{4}\right] \cdot x \mathrm{HO}-\mathrm{CH}_{2}-\mathrm{CH}_{2}-\mathrm{O}-\mathrm{CH}_{3} x \mathrm{H}_{2} \mathrm{O} \stackrel{110^{\circ} \mathrm{C}}{\longrightarrow}}
\end{aligned}
$$$$
\text { Gel }
$$$$
\mathrm{Zr}(\mathrm{OH})_{4} \stackrel{450^{\circ} \mathrm{C}}{\longrightarrow} \mathrm{ZrO}_{2} \text { (Zirconia) }
$$

Amorphous gel 


$$
\begin{aligned}
& \mathrm{Ti}\left(\mathrm{OC}_{4} \mathrm{H}_{9}\right)_{4}+\mathrm{HO}-\mathrm{CH}_{2}-\mathrm{CH}_{2}-\mathrm{O}-\mathrm{CH}_{3}+\mathrm{H}_{2} \mathrm{O} \stackrel{\mathrm{HNO}_{3}, \text { Hydrolysis }}{\longrightarrow} \\
& \mathrm{Ti}\left(\mathrm{OC}_{4} \mathrm{H}_{9}\right)_{2}(\mathrm{OH})_{2}+2 \mathrm{C}_{4} \mathrm{H}_{9} \mathrm{OH} \stackrel{\text { Polycondensation }}{\longrightarrow}
\end{aligned}
$$$$
\text { Sol }
$$$$
\left[\mathrm{Ti}(\mathrm{OH})_{4}\right] \cdot x \mathrm{HO}-\mathrm{CH}_{2}-\mathrm{CH}_{2}-\mathrm{O}-\mathrm{CH}_{3} \cdot x \mathrm{H}_{2} \mathrm{O} \stackrel{110^{\circ} \mathrm{C}}{\longrightarrow}
$$

Gel

$$
\mathrm{Ti}(\mathrm{OH})_{4} \stackrel{450^{\circ} \mathrm{C}}{\longrightarrow} \mathrm{TiO}_{2} \text { (Titania). }
$$

Amorphous gel

\subsection{Modification of titanium and zirconium electrode}

Ten $\mu$ l of bienzyme [Urease $\left(10 \mathrm{mg} \mathrm{mL}^{-1}\right)$ and GLDH $(1 \mathrm{mg}$ $\left.\left.\mathrm{mL}^{-1}\right)\right]$ solutions are spread over $\mathrm{TiO}_{2}-\mathrm{ZrO}_{2} / \mathrm{ITO}$ microelectrode by physisorption technique via electrostatic interactions and incubated for $3 \mathrm{~h}$ at $25{ }^{\circ} \mathrm{C}$ in humid condition. These bioelectrodes are stored in a refrigerator at $4{ }^{\circ} \mathrm{C}$ when not in use. The modified $\mathrm{TiO}_{2}-\mathrm{ZrO}_{2} / \mathrm{ITO}$ (WE1) and Urs-GLDH/TiO ${ }_{2}-$ $\mathrm{ZrO}_{2} / \mathrm{ITO}$ (WE2) act as working electrodes whereas a silver wire (0.5 mm dia.) coated with silver chloride $(\mathrm{Ag} / \mathrm{AgCl})$ layer is taken as the reference electrode for electrochemical studies.

\subsection{Integration of electrode with microfluidics channels}

PDMS microchannels have been fabricated using soft lithographic technique and include steps like cleaning of Si wafers, spin coating of photoresist, pre and post exposure heat treatment, UV exposure and development to obtain a positive relief pattern of the photoresist over Si wafers (called Master) of desired dimensions $(2 \mathrm{~cm} \times 200 \mu \mathrm{m} \times 200 \mu \mathrm{m}) .{ }^{19}$ The PDMS oligomer and a cross-linking agent mixed in 10:1 are stirred vigorously for about $5 \mathrm{~min}$ and are then degassed for about 30 min under vacuum to remove all air bubbles. The clear solution is poured onto the master and heated at $100{ }^{\circ} \mathrm{C}$ for about $1.5 \mathrm{~h}$. The PDMS layer with pattern of the negative relief is peeled off from the master and cut into suitable size. The reservoirs are fabricated by punching holes at the ends of microchannels. This PDMS chip is tightly clamped with the glass substrate containing ITO microelectrodes, to ensure leakage-free flow operation. The integration of PDMS microchannels and electrodes system for urea detection coupled with electrochemical analyzer is shown in Scheme 2.

\subsection{Instrumentation}

$\mathrm{X}$-ray diffraction (XRD, Rigaku), atomic force microscopic (AFM, Veeco, Nanoscope) and Fourier transform-infrared (FT-IR, Perkin-Elmer, Model 2000) techniques have been used for

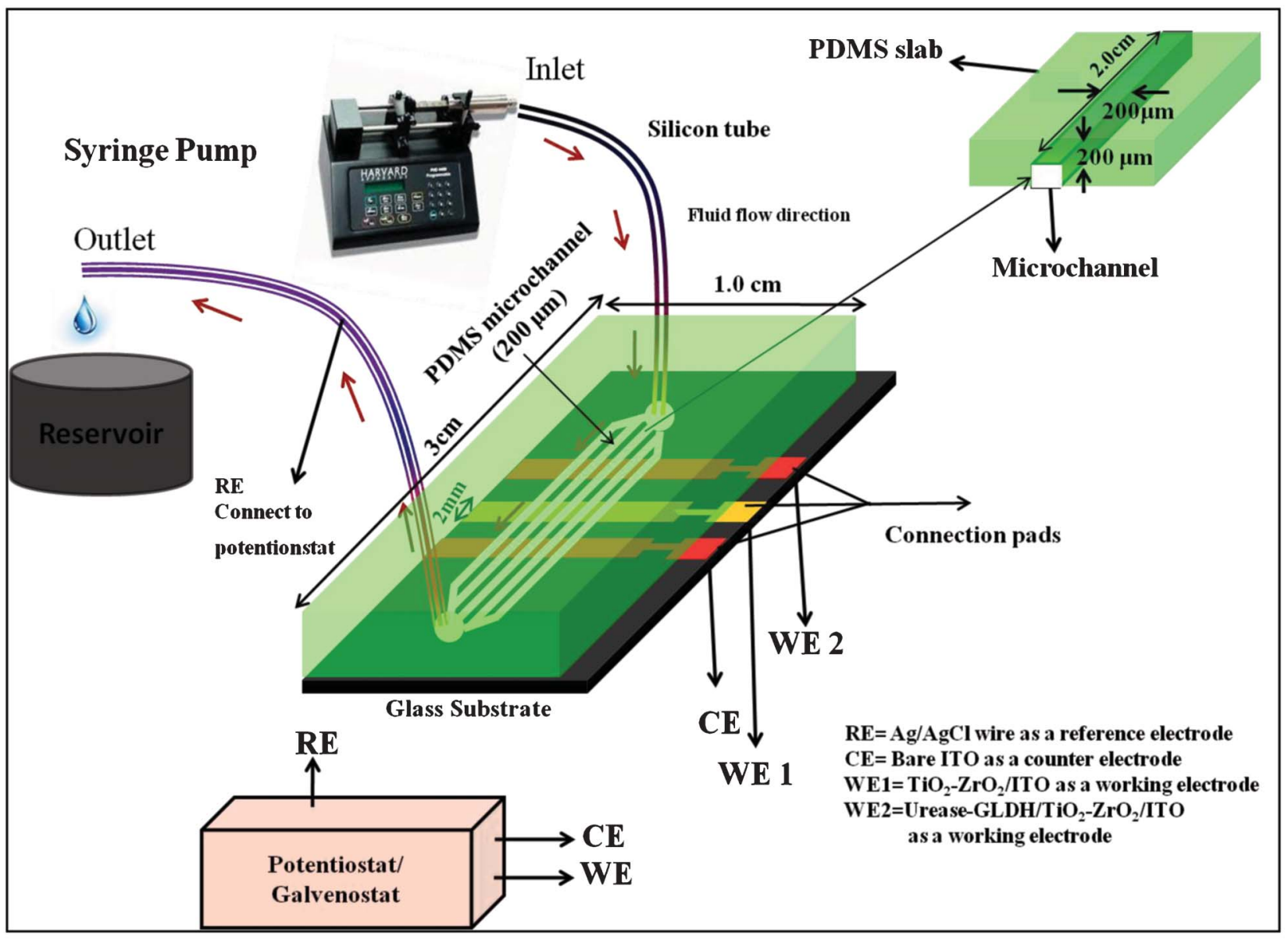

Scheme 2 Schematic representation of microfluidics module for $\mathrm{TiO}_{2}-\mathrm{ZrO}_{2}$ nanocomposites based electrochemical urea biosensor. 

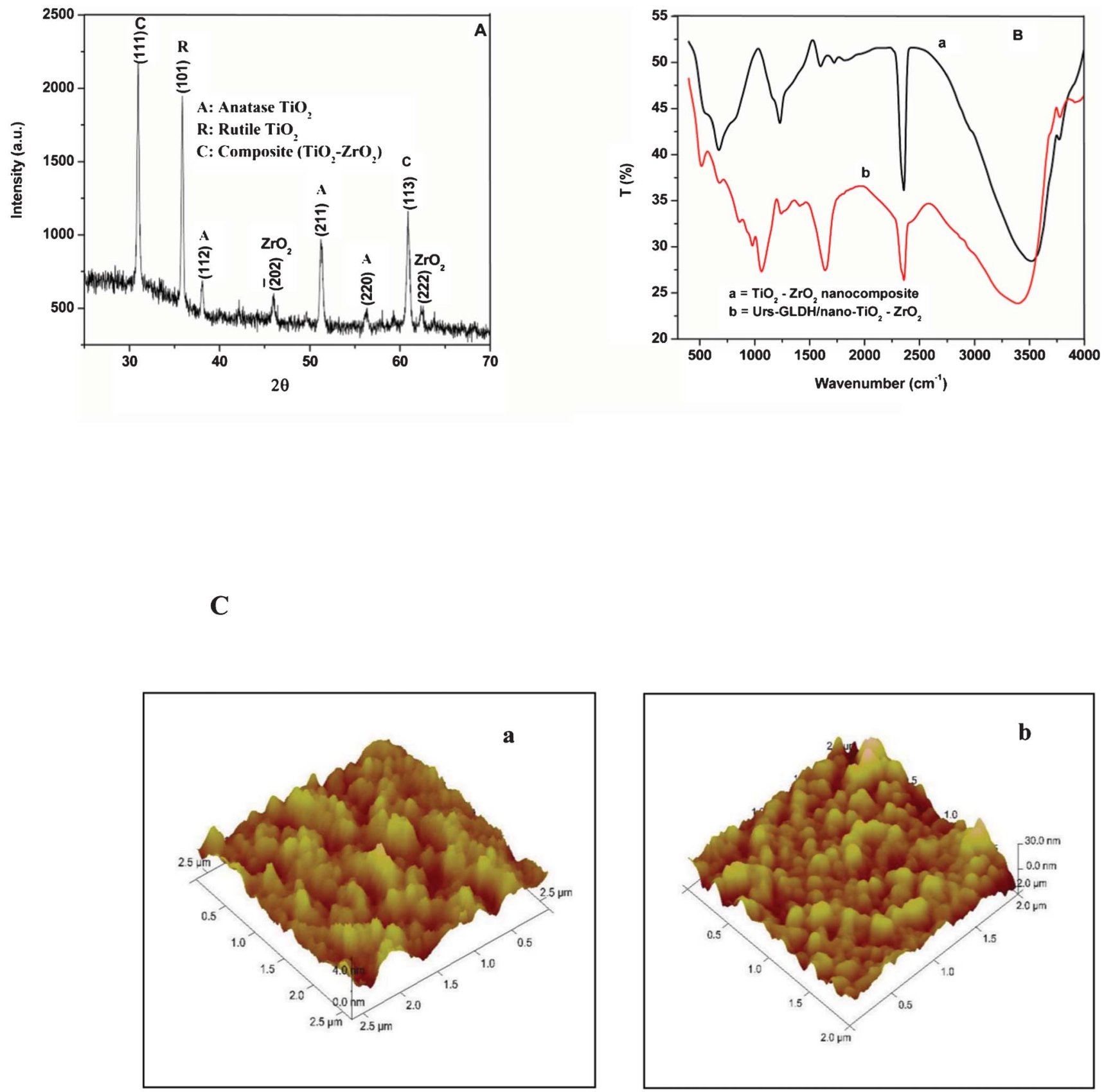

Fig. 1 (A) XRD pattern of $\mathrm{TiO}_{2}-\mathrm{ZrO}_{2}$ nanocomposite, (B) FTIR spectra of $\mathrm{TiO}_{2}-\mathrm{ZrO}_{2} /$ ITO electrode (a) and Urs-GLDH/TiO $\mathrm{Z}_{2}-\mathrm{ZrO}_{2} /$ ITO bioelectrode (b), (C) AFM image of $\mathrm{TiO}_{2}-\mathrm{ZrO}_{2} / \mathrm{ITO}$ (a) and Urs-GLDH/TiO $2-\mathrm{ZrO}_{2} / \mathrm{ITO}$ (b).

characterization of $\mathrm{TiO}_{2}-\mathrm{ZrO}_{2} / \mathrm{ITO}$ electrode and Urs-GLDH/ $\mathrm{TiO}_{2}-\mathrm{ZrO}_{2} / \mathrm{ITO}$ bioelectrode. Electrochemical studies have been performed in phosphate buffer saline (PBS, pH 7.0 containing $0.9 \% \mathrm{NaCl}$ ) using electrochemical analyzer (Autolab).

\section{Results and discussion}

\subsection{Structural properties}

The XRD pattern of $\mathrm{TiO}_{2}-\mathrm{ZrO}_{2}$ nanocomposite (Fig. 1A) shows peaks at $2 \theta: 30.7^{\circ}$ and $60.9^{\circ}$ corresponding to the diffraction pattern of (111) and (113) planes indicating the presence of predominant orthorhombic phase of $\mathrm{ZrTiO}_{4}$ (JCPDS 80-1783). The peak seen at $36^{\circ}$ corresponding to (101) plane represents the rutile phase present in $\mathrm{TiO}_{2}$. The peaks seen at $38^{\circ}, 51.4^{\circ}$ and $56.2^{\circ}$ correspond to the diffraction planes (112), (211) and (220) of anatase phase of $\mathrm{TiO}_{2}$. A small peak found at $62.6^{\circ}$ corresponds to (222) plane assigned to cubic crystalline system of $\mathrm{ZrO}_{2}$ (JCPDS 89-9069). The peak seen at $46^{\circ}$ corresponds to (202) reflection plane of $\mathrm{ZrO}_{2}$ (JCPDS 89-9066). The crystallite size of $\mathrm{TiO}_{2}-\mathrm{ZrO}_{2}$ nanocomposite calculated using Scherrer formula has been found as $17.8 \mathrm{~nm}$. 


\subsection{Optical properties}

The FT-IR spectra of $\mathrm{TiO}_{2}-\mathrm{ZrO}_{2} /$ ITO nanocomposite [Fig. 1B, (a)] exhibits characteristic peak at $664 \mathrm{~cm}^{-1}$ corresponding to vibration bending of Ti-O. A band seen at $740 \mathrm{~cm}^{-1}$ is ascribed to $\mathrm{ZrTiO}_{4}$ species. $^{20}$ The bands found at $3530 \mathrm{~cm}^{-1}$ and 1595 $\mathrm{cm}^{-1}$ correspond to the stretching vibration and deformation of the $\mathrm{O}-\mathrm{H}$ bond due to absorption of the water molecules. The FT-IR spectra of Urs-GLDH immobilized $\mathrm{TiO}_{2}-\mathrm{ZrO}_{2} / \mathrm{ITO}$ electrode (b) exhibits band at $1631 \mathrm{~cm}^{-1}$ (corresponding to $\mathrm{N}-\mathrm{H}$ bending), $1235 \mathrm{~cm}^{-1}$ (assigned to $\mathrm{C}-\mathrm{O}$ stretching) and $1061 \mathrm{~cm}^{-1}$ (corresponding to $\mathrm{C}-\mathrm{N}$ stretching) due to presence of amide bond revealing immobilization of Urs-GLDH onto nanocomposite. The weak bands seen at 1723 and $1812 \mathrm{~cm}^{-1}$ may perhaps be due to the formation of other intermediate compounds (acid derivative containing $\mathrm{C}=\mathrm{O}$ group) as a result of reaction of nitric acid and water to the hydrocarbon chain of the precursor (titanium(IV) butoxide/zirconium (IV) n-propoxide).

The AFM image [Fig. 1C, (image a)] shows that $\mathrm{TiO}_{2}-\mathrm{ZrO}_{2}$ molecules are uniformly distributed onto the ITO surface resulting in rough nanoporous structure with average roughness of $0.67 \mathrm{~nm}$. After co-immobilization of the enzymes (Urs and GLDH) (image b), the roughness increases to $3.81 \mathrm{~nm}$ revealing that nanoporous morphology of nanocomposite provides favorable environment for adsorption of enzymes. However, the average maximum height for $\mathrm{TiO}_{2}-\mathrm{ZrO}_{2} / \mathrm{ITO}$ electrode increases from 11.9 to $21 \mathrm{~nm}$ after enzyme immobilization. The observed granular structure is due to aggregation of the enzyme molecules over the nanocomposite platform.

\subsection{Electrochemical studies}

Fig. 2A shows results of the cyclic voltammetric (CV) studies conducted on $\mathrm{TiO}_{2}-\mathrm{ZrO}_{2} / \mathrm{ITO}$ electrode and Urs-GLDH/TiO ${ }_{2}-$ $\mathrm{ZrO}_{2} / \mathrm{ITO}$ bioelectrode in phosphate buffer saline (PBS; 50 $\mathrm{mM}, \mathrm{pH} 7.0,0.9 \% \mathrm{NaCl}$ ) at constant flow rate. Typical $\mathrm{CV}$ of $\mathrm{TiO}_{2}-\mathrm{ZrO}_{2}$ nanocomposite [curve (i)] shows different peaks at lower potentials of $0.057 \mathrm{~V}$ and $0.0039 \mathrm{~V}$ ( $\mathrm{vs} \mathrm{Ag} / \mathrm{AgCl})$ due to anatase crystal (a band) and interfacial sites (s band) of $\mathrm{TiO}_{2}$ (indicated by arrows $\mathbf{a}$ and $\mathbf{s}$ respectively) as reported in literature. ${ }^{17,18}$ Another broad oxidation peak found at higher potential $0.42 \mathrm{~V}$ is attributed to presence of $\mathrm{ZrO}_{2}$ (indicated by arrow) in $\mathrm{TiO}_{2}-\mathrm{ZrO}_{2}$ nanocomposite. ${ }^{17}$ The oxidation peak current in curve (ii) is higher $\left(1.11 \times 10^{-6} \mathrm{~A}\right)$ and is shifted to the lower potential $(0.334 \mathrm{~V})$ after immobilization of Urs and GLDH onto transducer surface. This may perhaps be due to the fact that the $\mathrm{TiO}_{2}-\mathrm{ZrO}_{2}$ nanocomposite provides favorable microenvironment for enzymes (Urs and GLDH) that directly communicate with the active sites and establish an electron mediation path and hence lower the tunneling distance between active sites of enzymes and electrode surface resulting in enhanced magnitude of current. Moreover, small peak appears at higher current $\left(3.27 \times 10^{-7} \mathrm{~A}\right)$ and is shifted towards lower positive potential $(+0.03 \mathrm{~V})$ due to a band of $\mathrm{TiO}_{2}$ system.

Cyclic voltammograms obtained for Urs-GLDH/TiO $-\mathrm{ZrO}_{2} /$ ITO bioelectrode as a function of scan rates $\left(20-100 \mathrm{mVs}^{-1}\right)$ have been shown in Fig. 2B. It is observed that the anodic
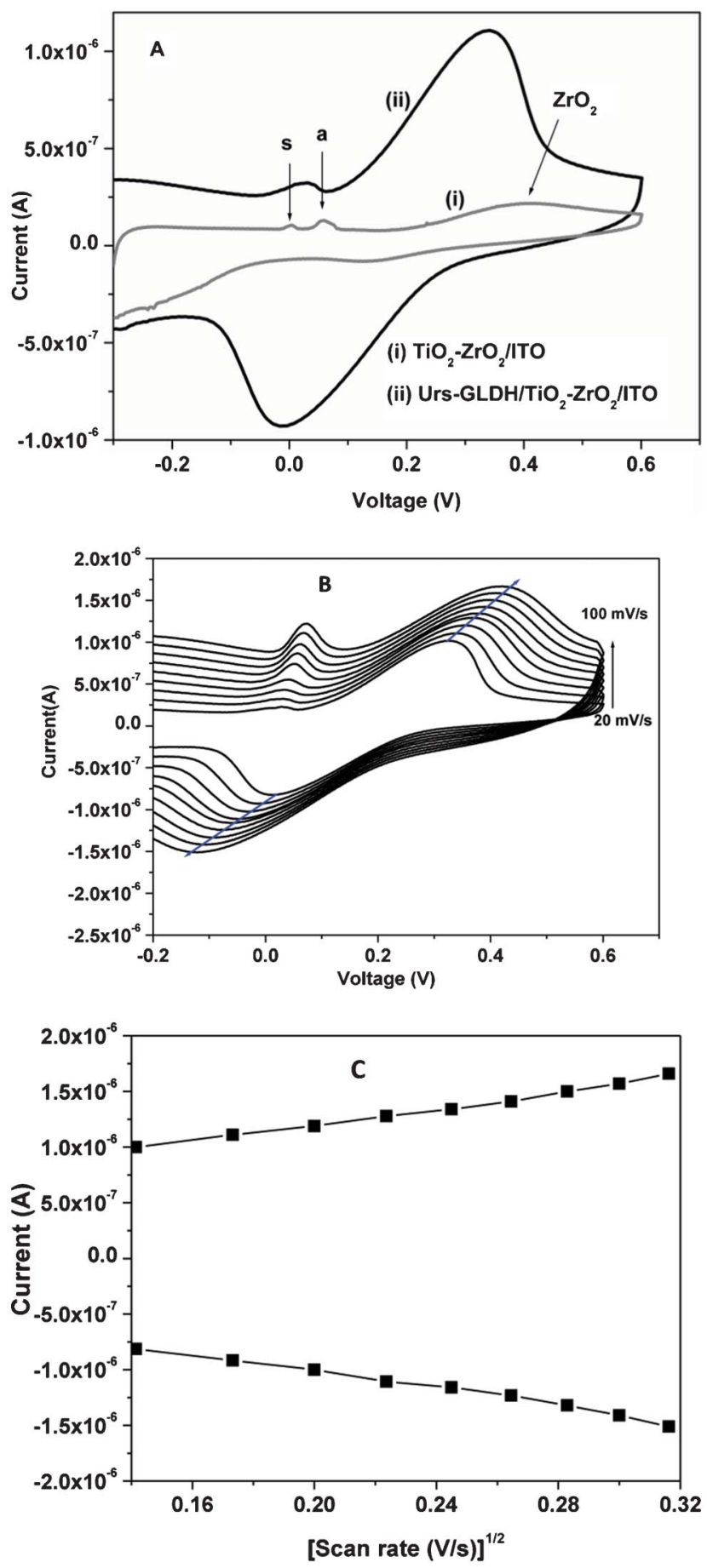

Fig. 2 (A) (i) Cyclic voltammetry (CV) of $\mathrm{TiO}_{2}-\mathrm{ZrO}_{2} / \mathrm{ITO}$ electrode and (ii) Urs$\mathrm{GLDH} / \mathrm{TiO}_{2}-\mathrm{ZrO}_{2} / \mathrm{ITO}$ bioelectrode in PBS, (B) CV of Urs-GLDH/TiO $2-\mathrm{ZrO}_{2} / \mathrm{ITO}$ bioelectrode at different scan rates in PBS. (C) Magnitude of redox peak currents as a function of square root of scan rate.

potential shifts towards positive side and the cathodic peak potential shifts in the reverse direction (Fig. 2C), indicating a diffusion electron-transfer process follows eqn $(3,4)$.

$$
\begin{aligned}
I_{\mathrm{a}}=4.63 & \times 10^{-7}[\mathrm{~A}]+3.68 \times 10^{-6}\left[\mathrm{~A}^{2} \mathrm{mV}^{-1} \mathrm{~s}\right]^{1 / 2} \\
\times & {\left[\text { scan rate }\left(\mathrm{mV} \mathrm{s}^{-1}\right)\right]^{1 / 2}, R^{2}=0.996 }
\end{aligned}
$$




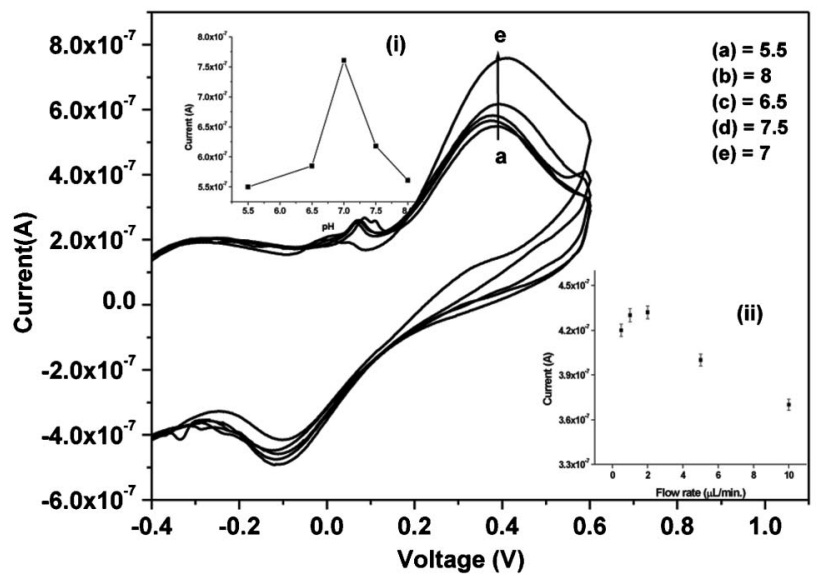

Fig. $3 \mathrm{CV}$ response of Urs-GLDH/TiO $-\mathrm{ZrO}_{2} / \mathrm{ITO}$ bioelectrode as a function of $\mathrm{pH}$ in PBS (5.5-8); inset (i): calibration curve between anodic peak current and $\mathrm{pH}$ value and inset (ii): shows the effect of flow rate on the response current

$$
\begin{gathered}
I_{\mathrm{c}}=-2.41 \times 10^{-7}[\mathrm{~A}]-3.87 \times 10^{-6}\left[\mathrm{~A}^{2} \mathrm{mV}^{-1} \mathrm{~s}\right]^{1 / 2} \\
\times\left[\mathrm{scan} \text { rate }\left(\mathrm{mV} \mathrm{s}^{-1}\right)\right]^{1 / 2}, R^{2}=0.995
\end{gathered}
$$

The surface concentration of Urs-GLDH/TiO $2-\mathrm{ZrO}_{2} / \mathrm{ITO}$ bioelectrode estimated from plot of $I_{\mathrm{p}}$ versus scan rate $(v)$ using the Brown-Anson model ${ }^{21}$ and found to be as $5.275 \times$ $10^{-12} \mathrm{~mol} \mathrm{~cm}{ }^{-2}$.

The effect of $\mathrm{pH}\left(5.5-8.0\right.$ at $\left.25{ }^{\circ} \mathrm{C}\right)$ on the Urs-GLDH/TiO ${ }_{2}^{-}$ $\mathrm{ZrO}_{2} /$ ITO bioelectrode has been investigated using $\mathrm{CV}$ to estimate optimum enzyme activity. The highest current (Fig. 3) is obtained at pH 7.0 revealing that bioelectrode is most active at this $\mathrm{pH}$. Thus, all the experiments are carried out at $\mathrm{pH}$ of 7.0 and temperature of $25{ }^{\circ} \mathrm{C}$. Inset (i) shows the anodic peak current as a function of $\mathrm{pH}$ using $\mathrm{CV}$.

The variation of response current obtained as a function of flow rate $\left(0.5,1,2,5\right.$ and $\left.10 \mu \mathrm{L} \mathrm{min}^{-1}\right)$ has been measured by taking $1 \mathrm{mM}$ urea concentration injected into the microchannel. It has been observed that the optimum flow rate is 2 $\mu \mathrm{L} \min ^{-1}$ at which the response current is maximum [inset (ii); Fig. 3]. The parameters which affect the current response are flux of electro active species and retention time for the biochemical reaction. As we increase the flow rate, the retention time is found to be lesser resulting in decreased response current. It has been found that the flux is increased as flow rate increases, but at the same time, the retention time reduces beyond the optimum value of $2 \mu \mathrm{L} \mathrm{min}{ }^{-1}$. This is due to the fact that the biomolecules are shifted away from the microchannels before completing the biochemical reaction onto the sensor surface.

In the fluid mechanics, Reynolds number $\left(R_{e}\right)$ is a dimensionless number that gives a measure of the ratio of inertial forces to viscous forces. The fluid flow through a microfluidics channels can be characterized by $R_{e}$ defined in eqn (5)

$$
R_{e}=\frac{\rho v L}{\mu}
$$

where $L$ is the characteristic length $(200 \mu \mathrm{m})$ of channels, $\mu$ is
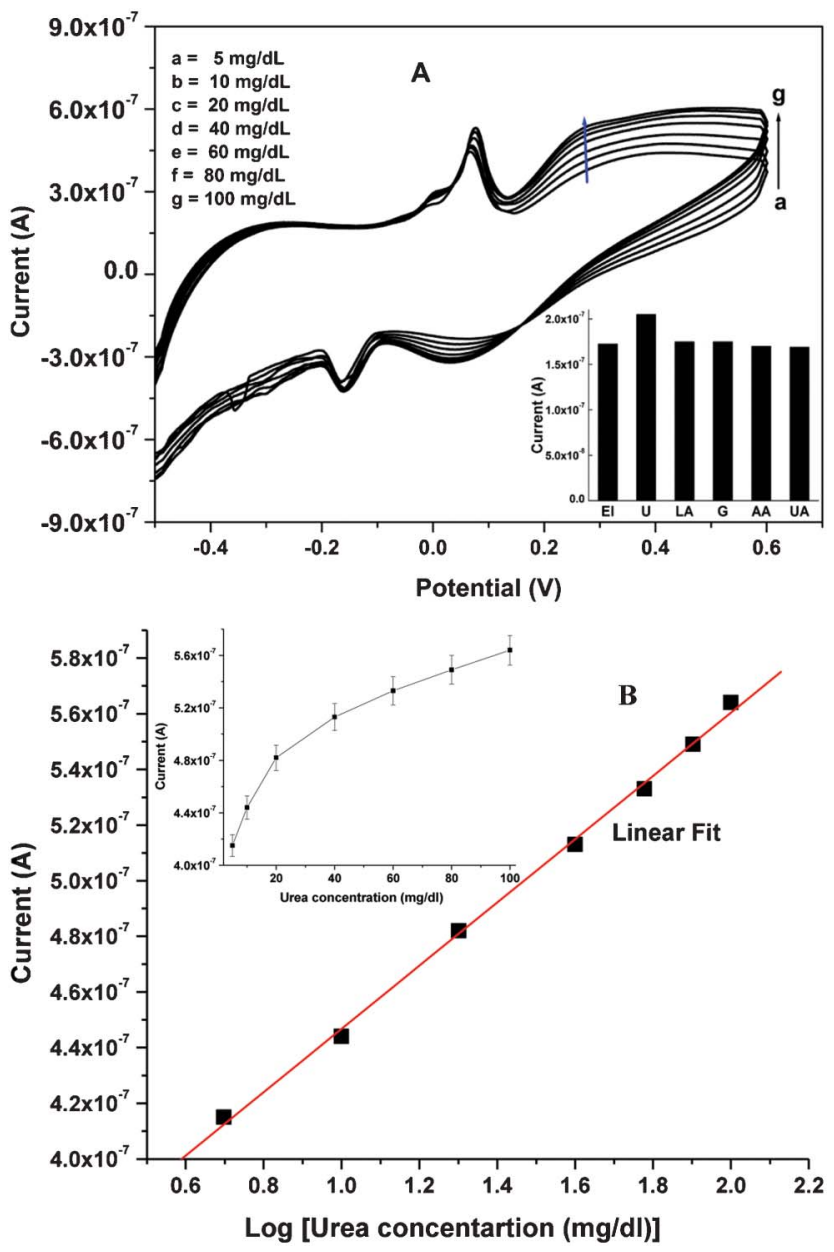

Fig. 4 (A) $\mathrm{CV}$ response of Urs- $\mathrm{GLDH} / \mathrm{TiO}_{2}-\mathrm{ZrO}_{2} / \mathrm{ITO}$ bioelectrode as a function of urea concentration in PBS. Inset shows the effect of interferents (glucose, ascorbic acid, uric acid and lactic acid) on the current response of the Urs-GLDH/ $\mathrm{TiO}_{2}-\mathrm{ZrO}_{2} / \mathrm{ITO}$ bioelectrode in PBS. (B) Calibration curve between response current and log urea concentration (5-100 mg/dl); inset (i) shows calibration curve between response current and urea concentration (5-100 mg/dl).

the viscosity $\left(10^{-3} \mathrm{~Pa} \mathrm{~s}\right), v$ is average velocity of fluid $(0.083 \times$ $\left.10^{-2} \mathrm{~m} \mathrm{~s}^{-1}\right)$ and $\rho$ is fluid density $\left(10^{3} \mathrm{~kg} \mathrm{~m}^{-3}\right)$ from which the magnitude of $R_{e}$ number comes out to be 0.166 indicating fluid flow is completely laminar and mass transfer occurs mainly by diffusion.

\subsection{Electrochemical response studies}

Electrochemical response studies of Urs-GLDH/TiO $-\mathrm{ZrO}_{2} / \mathrm{ITO}$ bioelectrode have been conducted as a function of urea in presence of NADH and $\alpha-\mathrm{KG}$ [Fig. 4A] in PBS, injected into the microchannels at continuous flow rate of $2 \mu \mathrm{L} \min ^{-1}$ using $\mathrm{CV}$. The magnitude of response peak current increases as urea concentration increases. In proposed biochemical reaction (Scheme 3), urease catalyzes hydrolysis of urea to carbamine acid that gets hydrolyzed to ammonia $\left(\mathrm{NH}_{3}\right)$ and carbon dioxide $\left(\mathrm{CO}_{2}\right)$. GLDH catalyzes the reversible reaction between $\alpha-\mathrm{KG}$ and $\mathrm{NH}_{3}$ to $\mathrm{NAD}^{+}$and linked oxidative deamination of L-glutamate in two steps. The first step involves a Schiff base intermediate formed between $\mathrm{NH}_{3}$ and $\alpha$-KG (Step A). Then 


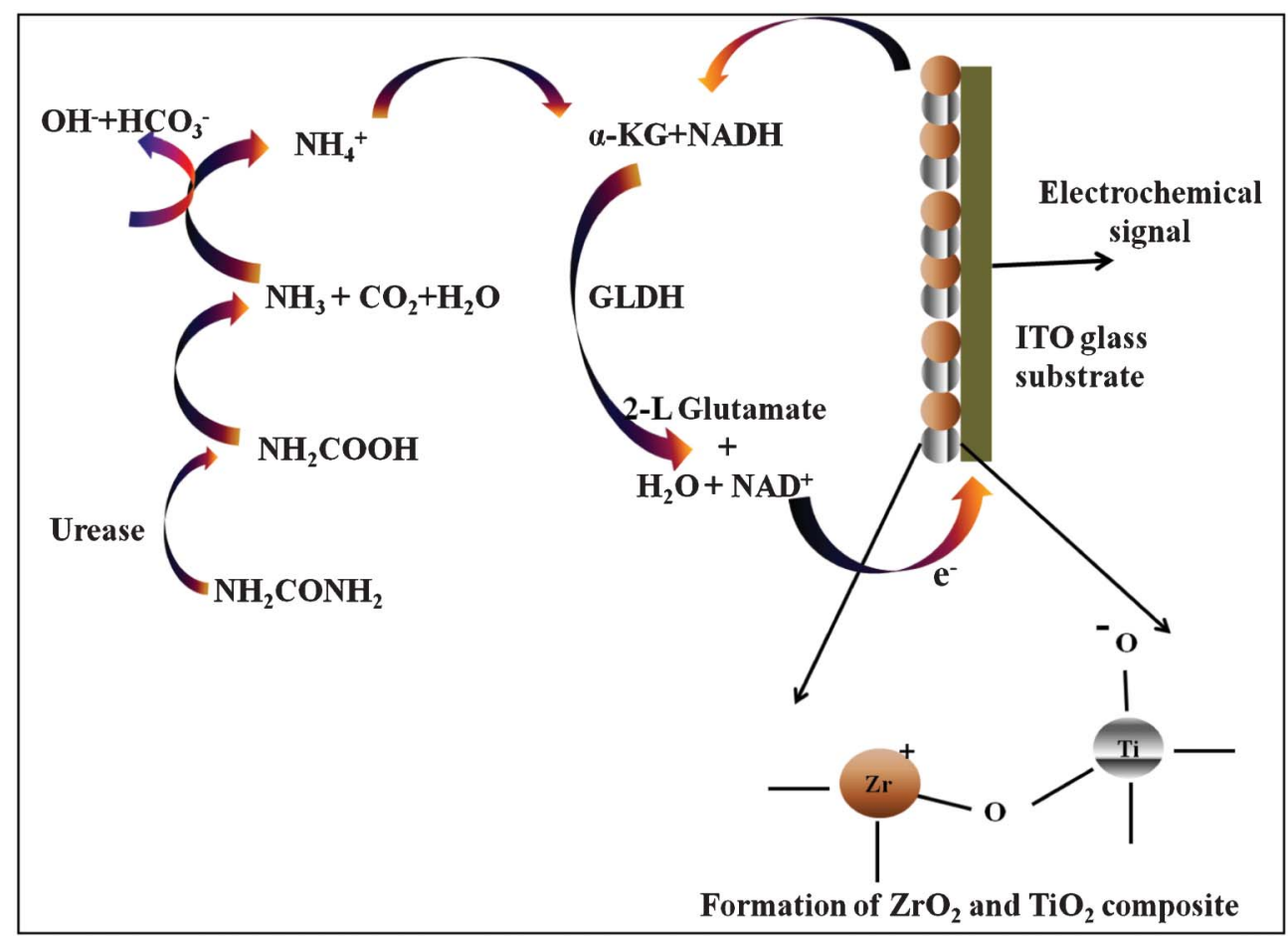

Scheme 3 Showing biochemical reaction and electron transfer mechanism at the electrode surface.

Schiff base intermediate protonated due to transfer of the hydride ions from NADH resulting in formation of L-glutamate (Step B). NAD ${ }^{+}$is utilized in the forward reaction of $\alpha-\mathrm{KG}$ and free $\mathrm{NH}_{3}$ that is converted to L-glutamate via hydride transfer from $\mathrm{NADH}$ to glutamate. $\mathrm{NAD}^{+}$is utilized in the reverse reaction, involving L-glutamate being converted to $\alpha$-KG and free $\left(\mathrm{NH}_{3}\right)$ via oxidative deamination reaction. The electrons generated during these reactions are transferred to $\mathrm{TiO}_{2}-\mathrm{ZrO}_{2} /$ ITO electrode.

$\left(\mathrm{NH}_{2}\right)_{2} \mathrm{CO}+3 \mathrm{H}_{2} \mathrm{O} \stackrel{\text { Urease }}{\longrightarrow} 2 \mathrm{NH}_{4}^{+}+\mathrm{OH}^{-}+\mathrm{HCO}_{3}^{-}($Step A) $(6)$

$$
\begin{aligned}
& \mathrm{NH}_{4}^{+}+\alpha-\text { ketoglutarate }+\mathrm{NADH} \stackrel{\text { GLDH }}{\longrightarrow} \\
& \mathrm{L}-\text { glutamate }+\mathrm{NAD}^{+}+2 \mathrm{e}(\text { Step B })
\end{aligned}
$$

Fig. 4B shows the calibration plot between anodic peak current and log of urea concentration (5-100 mg/dL) and inset (i) shows the calibration plot between peak current $v s$. urea concentration $(5-100 \mathrm{mg} / \mathrm{dL})$. The lower detection limit is obtained as $0.07 \mathrm{mg} / \mathrm{dL}$ using the $3 \sigma_{\mathrm{b}} / \mathrm{m}$ equation, where $m$ is slope and $\sigma_{\mathrm{b}}$ is standard deviation of the calibration graph. The linear range is obtained as $5-100 \mathrm{mg} / \mathrm{dl}$ with sensitivity as 2.74 $\mu \mathrm{A}[\mathrm{Log} \mathrm{mM}]^{-1} \mathrm{~cm}^{-2}$. The higher sensitivity obtained as compared to reported data ${ }^{8,12,22,23}$ is not only due to the small geometry of microfluidics device, but also larger surface-tovolume ratio of nanocrystalline $\mathrm{TiO}_{2}-\mathrm{ZrO}_{2}$ nanocomposite which increases surface density of enzyme loading. This microfluidics sensor for urea detection shows faster response time (10 s) attributed to small characteristic diffusion length towards microelectrode.

The shelf-life of the microfluidics sensor has been estimated by measuring electrochemical current response with respect to time, in a regular interval of 1 week. It is observed that this bioelectrode retains about $85 \%$ of the enzymes (Urs and

\begin{tabular}{|c|c|c|c|c|c|c|}
\hline Urs-GLDH/ZnO-Ch/ITO & $0.8-16.6$ & 0.49 & $0.13 \mu \mathrm{AmM}^{-1} \mathrm{~cm}^{-2}$ & 10 & no & 8 \\
\hline Urs-GLDH/ZrO ${ }_{2} / \mathrm{ITO}$ & $0.8-16.6$ & 0.8 & $0.07 \mu \mathrm{A} \mathrm{mM}{ }^{-1} \mathrm{~cm}^{-2}$ & 10 & no & 12 \\
\hline Urs-GLDH/Nano-ZnO/ITO & $0.8-13.3$ & 2.24 & $8.7 \mu \mathrm{A} \mathrm{mM}-1 \mathrm{~cm}^{-2}$ & - & no & 24 \\
\hline EG-Ag-Z-Epoxy & $0.2-1.4$ & 0.05 & $30 \mu \mathrm{A} \mathrm{mM} M^{-1} \mathrm{~cm}^{-2}$ & 50 & no & 25 \\
\hline
\end{tabular}

Table 1 Comparing sensing performance of the $\mathrm{TiO}_{2}-\mathrm{ZrO}_{2}$ nanocomposite based microfluidics urea biosensor along with some of those reported in the literature 
GLDH) activity even after about 4 weeks when stored in refrigerated conditions $\left(4^{\circ} \mathrm{C}\right)$ after which the current response decreases to $80 \%$ in about 6 weeks (data not shown). The reproducibility of response of bioelectrode has been investigated using $10 \mathrm{mg} / \mathrm{dL}$ urea concentration. No significant decrease in current is observed after using at least 12 times.

The selectivity of Urs-GLDH/ $\mathrm{TiO}_{2}-\mathrm{ZrO}_{2} / \mathrm{ITO}$ bioelectrode (El) has been determined by comparing magnitude of the current response with individual normal concentration of interferents such as glucose (5 mM), ascorbic acid (0.05 mM), uric acid (0.1 $\mathrm{mM})$ and lactic acid (5 $\mathrm{mM})$ along with urea $(1 \mathrm{mM})$ in PBS as shown in inset of Fig. 4A. Results of these studies indicate that the Urs-GLDH/ $/ \mathrm{TiO}_{2}-\mathrm{ZrO}_{2} / \mathrm{ITO}$ bioelectrode is highly specific for the detection of urea only and exhibits negligible interference with other analytes.

The sensing performance of this $\mathrm{TiO}_{2}-\mathrm{ZrO}_{2}$ nanocomposite based microfluidics urea biosensor has been summarized in Table 1 along with those reported in the literature.

\section{Conclusions}

We have demonstrated the fabrication of a highly sensitive mediator-free microfluidics sensor comprising of PDMS microchannels, patterned electrodes for the rapid detection of urea. Urs and GLDH have been successfully co-immobilized onto $\mathrm{TiO}_{2}-\mathrm{ZrO}_{2}$ nanocomposite microelectrodes surface. This mediator-free microfluidics sensor offers improved sensitivity, detection limit and fast response time. This is attributed to the good electrocatalytic behavior of the nanocomposite as well as smaller geometry of the sensor. The reproducibility of bioelectrode has been investigated as 12 times. Efforts should be made to utilize this $\mathrm{TiO}_{2}-\mathrm{ZrO}_{2}$ nanocomposite microfluidics device for the estimation of other important analytes including cholesterol and low density lipoprotein.

\section{Acknowledgements}

We thank Director, National Physical Laboratory, New Delhi, India for providing the facilities. Saurabh Srivastava and Md. Azahar Ali are thankful to CSIR, India for the award of Senior Research Fellowship. Financial support received under the DST sponsored project (DST/TSG/ME/2008/18) is gratefully acknowledged. We are thankful to Mr. Sandeep Singh for AFM studies.

\section{References}

1 G. M. Whitesides, Nature, 2006, 442, 368.
2 J. A. Wells, S. Vollmer, T. Bergman and H. Jornvall, Anal. Biochem., 2005, 345, 10.

3 B. S. Lee, Y. U. Lee, H. S. Kim, T. H. Kim, J. Park, J. G. Lee, J. Kim, H. Kim, W. G. Lee and Y. K. Cho, Lab Chip, 2011, 11, 70.

4 Q. Xue, A. Wainright, S. Gangakhedkar and I. Gibbons, Electrophoresis, 2001, 22, 4000.

5 G. M. Whitesides, E. Ostuni, S. Takayama, X. Jiang and D. E. Ingber, Annu. Rev. Biomed. Eng., 2001, 3, 335.

6 H. B.-Yoav, P. H. Dykstra, W. E. Bentley and R. Ghodssi, Biosens. Bioelectron., 2012, 38, 114.

7 P. R. Solanki, A. Kaushik, V. V. Agrawal and B. D. Malhotra, NPG Asia Mater., 2011, 3, 17.

8 A. Kaushik, P. R. Solanki, A. A. Ansari, G. Sumana, S. Ahmad and B. D. Malhotra, Sens. Actuators, B, 2009, 138, 572.

9 P. R. Solanki, A. Kaushik, A. A. Ansari, G. Sumana and B. D. Malhotra, Appl. Phys. Lett., 2008, 93, 163903.

10 S. A. Kumar, P.H. Lo and S. M. Chen, Nanotechnology, 2008, 19, 255501.

11 S. Liu, Z. Dai, H. Chen and H. Ju, Biosens. Bioelectron., 2004, 19, 963.

12 G. Sumana, M. Das, S. Srivastava and B. D. Malhotra, Thin Solid Films, 2010, 519, 1187.

13 G. Dhawan, G. Sumana and B. D. Malhotra, Biochem. Eng. J., 2009, 44, 42.

14 B. Lakard, G. Herlem, S. Lakard, A. Antoniou and B. Fahys, Biosens. Bioelectron., 2004, 19, 1641.

15 Y. Velichkova, Y. Ivanov, I. Marinov, R. Ramesh, N. R. Kamini, N. Dimcheva, E. Horozova and T. Godjevargova, J. Mol. Catal. B: Enzym., 2011, 69, 168.

16 X. Wang, J. C. Yu, Y. Chen, L. Wu and X. Fu, Environ. Sci. Technol., 2006, 40, 2369.

17 K. L. Frindell, J. Tang, J. H. Harreld and G. D. Stucky, Chem. Mater., 2004, 16, 3524.

18 D. Keomany, J. P. Petit and D. Deroo, Sol. Energy Mater. Sol. Cells, 1995, 36, 397.

19 S. Srivastava, P. R. Solanki, A. Kaushik, Md. A. Ali, A. Srivastava and B. D. Malhotra, Nanoscale, 2011, 3, 2971.

20 B. M. Reddy and B. Chowdhury, J. Catal., 1998, 179, 413.

21 A. J. Bard and L. R. Faulkner, Electrochemical Methods: Fundamentals and Applications, 2nd ed., Wiley, New York.

22 V. Rajesh, W. Bisht, W. Takashima and K. Kaneto, Biomaterials, 2005, 26, 3683.

23 J. M. C. S. Magalhaes and A. A. S. C. Machado, Talanta, 1998, 47, 191.

24 A. Ali, A. A. Ansari, A. Kaushik, P. R. Solanki, A. Barik, M. K. Pandey and B. D. Malhotra, Mater. Lett., 2009, 63, 2473.

25 F. Manea, A. Pop, C. Radovan, P. Malchev, A. Bebeselea, G. Burtica, S. Picken and J. Schoonman, Sensors, 2008, 8, 5806. 